Journal of Animal and Veterinary Advances 18 (5): 154-168, 2019

ISSN: $1680-5593$

(C) Medwell Journals, 2019

\title{
Multicriteria Appraisal of the Potential of Converting Cattle Raising to Organic Production in the Humid Tropics of Chiapas, Mexico
}

\author{
${ }^{1}$ Ingrid Abril Valdivieso Perez, ${ }^{1}$ Jose Nahed Toral, ${ }^{1}$ Guillermo Jimenez Ferrer, \\ ${ }^{2}$ Angel T. Pineiro Vazquez, ${ }^{1}$ Manuel Parra Vazquez and ${ }^{3}$ Francisco Guevara Hernandez \\ ${ }^{1}$ Departamento de Agricultura, Sociedad y Ambiente, El Colegio de la Frontera Sur, \\ Carretera Panamericana y Periferico Sur S/N, Barrio Ma. Auxiliadora, \\ San Cristobal de las Casas, 29290 Chiapas, Mexico \\ ${ }^{2}$ Tecnologico Nacional de Mexico/I. T. Conkal, Division de Estudios de Posgrado e Investigacion \\ Avenida Tecnologico S/N, Conkal, 97345 Yucatan, Mexico \\ ${ }^{3}$ Facultad de Ciencias Agronomicas, Universidad Autonoma de Chiapas, Carretera Ocozocoautla \\ Villaflores Km. 84.5 Apartado postal \#78, 30470 Villaflores, Chiapas Chiapas, Mexico
}

\begin{abstract}
This study characterizes technical and economic aspects of conventional dual-purpose (milk and meat) cattle raising in the humid tropics of Chiapas, Mexico and evaluates the potential for converting these farms to organic-or clean-production. An organic livestock raising conversion index with 10 indicators and 37 variables was used. Data was obtained through direct observation and a questionnaire applied to 50 farmers. Through a Cluster analysis $(C)$, we classified Livestock Production Units (LPU) into three groups $(\mathrm{p}<0.05)$. The highest values $(\mathrm{p}<0.05)$ for the technical-economic indicators as well as ICOGAN were found for the LPU of C3, followed by those of C2 and finally, C1. All LPU evaluated scored very low for the indicators "veterinary prevention and care" and "ecological farm management". The LPU of all three C scored high for the indicators "breeds and reproduction" and "soil fertilization". In order for the LPU to increase their levels of sustainability and be certified organic, there is a need to strengthen farmer's abilities in techniques of ecological production and management through technical advisory and assistance as well as permanent financial support. Furthermore, there is a need for all social actors involved to have a sense of co-responsibility for and be committed to the organic conversion process as well as a need for significant changes in state and federal cattle raising policies.
\end{abstract}

Key words: Organic conversion, indicators, ecological agriculture, sustainability, assistance, social

\section{INTRODUCTION}

As people's health depends on the quality and safety of the food they consume, UNICEF (2016) indicates that food for the human population should be safe have high organoleptic-sensory quality and be nutritious, regardless of the type or scale of the agrifood system from which it originates. In many parts of the world, the population increasingly demands that their food be highly nutritious and harmless to their health and that it be environmentally friendly. However, food's safety, nutritional level and organoleptic-sensory quality depends on its management throughout the production chain. Therefore, foods vary with respect to these three aspects of their quality as they originate from different types of agricultural and food processing systems.

From the Neolithic period almost until the mid-XX century, agriculture was natural (without agrochemicals) and food was healthy and nutritious (Reganold and
Wachter, 2016). Following the Second World War, the dominant type of agriculture which became known as the "Green Revolution" model was developed based on genetic improvement as well as intensive natural resource use, agrochemicals (fertilizers, fungicides, insecticides and herbicides); allopathic medicines (antibiotics, hormones and anti-parasitic medicines); irrigation, transportation and refrigeration systems; farm equipment dependent on fossil fuel and biotechnology.

While this type of agriculture substantially increased short-term production of food crops and livestock, it gradually became clear that the dominant food system was unsustainable due to unforeseen direct and indirect consequences including depletion of soil fertility, soil and water contamination, severe and even chronic intoxication due to agrochemical use, loss of agrobiodiversity, increased socioeconomic inequality and reduction in mid and long-term production levels (IFOAM., 2009; Reganold and Wachter, 2016).

Corresponding Author: Jose Nahed Toral, Departamento de Agricultura, Sociedad y Ambiente, El Colegio de la Frontera Sur, Carretera Panamericana y Periferico Sur S/N, Barrio Ma. Auxiliadora, San Cristobal de las Casas, 29290 Chiapas, Mexico Tel: (01967) 6749000 
This critical situation led to development of certified organic and otherwise ecological agriculture with many similarities to that practiced centuries ago as well as to different forms of traditional agriculture still practiced in many places today. Cultivation of organic and ecological food concords with many principles of clean production which aim to prevent risks to consumer health and the environment and also contributes to food security as mentioned, for example, in the 1978 Alma-Ata Declaration of the International Conference on Primary Healthcare. Such prevention of health and environmental risks is due to the fact that organic food is produced according to principles of health, agroecology, equity, precaution, responsibility and sustainability promotes human health and life on Earth given that it allows for naturally conserving integrated soil-plant-animal cycles, the environment and biodiversity; favors animal well-being; avoids use of agrochemicals and conserves energy) provides consumers with safe, nutritious food with high organoleptic quality and) is produced in agroeco systems which are energetically more efficient and produce fewer greenhouse gas emissions than food produced with high levels of external inputs and may even reduce greenhouse gases produced by other sources (IFOAM., 2009; Gerber et al., 2009).

Certified organic agriculture is beginning to be introduced in many nations, particularly in the Global South due to the fact that producing safe nutritious food has become key to marketing products. For this reason, governments, Non-Governmental Organizations (NGOs), agribusiness and individual farmers of so-called "developed nations" as well as those of the global South are interested in evaluating their agricultural technologies and processes as well as the quality of their farm products in order to identify limitations to the quality of their food products and implement corrective measures to be able to compete in local, national and international markets (Reganold and Wachter, 2016).

Currently, 43.7 million hectares worldwide are used for certified organic agriculture (Lernoud and Schlatter, 2016). The continent with the most land devoted to organic agriculture is Oceania (17.3 million ha), followed by Europe (11.6 million ha), Latin America (6.8 million ha), Asia (3.6 million ha), North America (3.1 million ha) and Africa (1.3 million ha) (Lernoud and Schatter, 2016). Mexico which takes third place worldwide with respect to number of organic farmers $(169,703)$ who devote a majority of their cropland to coffee has 501, 364 ha $(2.3 \%$ of its agricultural surface area) under organic production (Lernoud and Schlatter, 2016).

In order to assure consumers and certifying organizations that agricultural products are organic, there is a need for clear, precise, concise indicators to evaluate whether food production is based on the principles of organic agriculture (Lernoud and Schlatter, 2016).
Existing studies report indicators for evaluating agricultural sustainability (Kouba, 2003; Coffey et al., 2010; Peacock and Sherman, 2010), animal well-being (Napolitano et al., 2009; Phythian et al., 2011) and environmental effects on milk quality on organic farms (De Boer, 2003; Nauta et al., 2006; Rozzi et al., 2007; Muller-Lindenlauf et al., 2010) or rate technical and economic performance of livestock production units (Escribano, 2016) or farmer attitudes toward converting their conventional farm to organic production (Midmore et al., 2001) or even criticize organic livestock raising on the basis that animals may be undernourished and infested with parasites due to restrictions in use of anthelmintics (Vaarst et al., 2005). However, literature referring to use of indicators to evaluate the feasibility of transition from conventional to organic farming is scarce (Bellon and Lamine, 2009) for some such existing studies, (Olivares et al., 2005, Mena et al., 2012).

Studies using indicators to evaluate the possibility of transitioning conventional farms to organic production allow for orienting further research as well as policies and other mechanisms for organic conversion as well as identifying limitations, potential and opportunities of existing farm systems, so that, government agencies and NGOs with the support of researchers-may design strategies for transitioning toward organic production (Scoones 1998; Escribano, 2016). Functional limitations to organic farming those which are a result of conventional agricultural practices-may be overcome by substituting one factor of production with another, for example, chemical fertilizer with organic fertilizer or chemical pest control with biological forms of control. Structural limitations on the other hand are a result of the larger economic and political context that prevents development of organic agriculture and are difficult to modify. Rather, their transformation requires multiple changes to the sociopolitical structure (Long and Villareal, 1992). The present study principally identifies functional limitations to converting conventional livestock raising to organic production.

Organic certification of animal products improves market options by allowing farmers to compete in agrifood markets (Nahed-Toral et al., 2013; Reganold and Wachter, 2016), market their products in specialized niches and raise product prices. In order to identify comparative advantages of organic farm technologies and practices and the quality of resulting animal products, there is a need to develop methodologies to evaluate these technologies and products (Mena et al., 2012; Escribano, 2016).

Many regions of Mexico including some parts the state of Chiapas are suitable for converting conventional farms to organic production given that they already use few external inputs (Nahed-Toral et al., 2010). Nevertheless, currently almost all of Mexico's 
farm products are marketed as conventional. In 2016, Mexico produced 1.88 million tons of carcass meat with the state of Chiapas ranking third, producing $6.1 \%$ of the nation's meat. Meanwhile, in 2017, 11,607,493 L of milk was produced in Mexico 423,965 L of this in Chiapas. In the municipality of Tecpatan, Chiapas in 2016, 2,646.78 tons of carcass meat and 40,410.35 L of milk were reportedly produced and several studies considered livestock systems in this municipality to have a high potential for transitioning from conventional to organic production (Nahed-Toral et al., 2010, 2013). Currently, Chiapas ranks first nation-wide in surface area of organic food production, largely due to its large surface area planted in organic coffee.

In Southeastern Mexico, conventional dual purpose cattle raising generally, involves low levels of external inputs (Nahed-Toral et al., 2010), along with extensive grazing with varying levels of tree cover and histories of use crop associations of basic grains (principally maize and beans): rotation of land use (for example, among forest, pasture, crops and fallows) and use of trees and shrubs for fodder (Nahed-Toral et al., 2012). Farms generally have low levels of technology and capital investment according to the following indicators) use of family labor, farm infrastructure use of manual tools, basic services (such as roads, electricity, water and communications) and training and advisory. Furthermore, farmers lack direct outlets to sell their products to food processors and marketers (Nahed-Toral et al., 2012). There is a need to identify limitations, potential and opportunities of these traditional agrosilvopastoral systems with the objective of facilitating their transition toward organic certification and sustainability. With this in mind, the objective of the present study was to evaluate the potential for conversion of conventional dual purpose Livestock Production Units (LPU) to the organic production model in the municipality of Tecpatan, Chiapas.

\section{MATERIALS AND METHODS}

Location and characterization of the study area: The municipality of Tecpatan (including the recently formed municipality of Mezcalapa) is located in the Zoque ethnic region, in the humid tropics of the Northeastern region of the Mexican State of Chiapas, between $93^{\circ} 15^{\prime}$ and $93^{\circ} 52^{\prime}$ West longitude and $16^{\circ} 59^{\prime}$ and $17^{\circ} 23^{\prime}$ North latitude. Tecpatan is located in the mid-watershed of the Grijalva River within the Mesoamerican Biological Corridor. Altitude ranges from 80-1,100 MASL with an average of 320 MASL and most of the municipality's topography is rugged. About $65 \%$ of its soil is luvisol and lesser proportions are cambisol (8.3\%), phaeozem (3.9\%), plintosol (3.48\%) and leptosol $(0.61 \%)$; the remaining surface area consists of bodies of water. Soil $\mathrm{pH}$ ranges from 5.13-6.45. According to the Koppen classification modified by Garcia, climate is warm-humid with abundant Summer rain (Af (m) w' (i ') g). Most precipitation falls from June to November and the hottest months are April to June. In the municipal seat of Tecpatan, average annual temperature is $25^{\circ} \mathrm{C}$ and average annual precipitation 1,932 $\mathrm{mm}$. Tecpatan has an extensive hydrographic network; the longest waterway is the Grijalva (or Mezcalapa) river which drains into the reservoir of the Netzahualcoyotl dam. In 2018, the municipality's population was reported to be 41,045 (20,420 male and 20,625 female), living in 359 towns and villages. Aside from monolingual Spanish speakers, the population includes 6,572 indigenous bilingual (Spanish and Zoque) speakers as well as 610 monolingual (Zoque) speakers. According to INEGI, Tecpatan had 4,495 agricultural and/or forestry production units in a total surface area of $67,619.18$ ha, 2,628 of which raised cattle (study universe). These LPU have an average of 25 head of cattle and farm families raise a variety of crops and animals for self-consumption as well as for sale.

Estimation of sample size: Of the 2,628 LPU in the study area, a sample size was estimated using the following simple random sampling equation:

$$
\mathrm{n}_{0}=\frac{\mathrm{z}^{2} \mathrm{pq}}{\mathrm{d}^{2}}
$$

Where:

$\mathrm{n}_{0}=$ Sample size

$\mathrm{z}^{2}=$ Risk set at 1.96

$\mathrm{p}=$ Estimated proportion of livestock raising population in the region $(85 \%)$

$\mathrm{q}=1-\mathrm{p}$

$\mathrm{d}=$ Maximum error permitted $(10 \%)$

A value of $50 \mathrm{LPU}$ was obtained for analysis. In order to select these LPU, we carried out an intentional search of segments (LPU) that represent the typology of the farms, beginning with those whose owners had participated in other projects with researchers of the present study (Nahed et al., 2018). In order to reach a sample size of $50 \mathrm{LPU}$, after selecting several farmers who agreed to participate in the study, we asked them to propose other farmers with different types of management in order to be able to contrast those LPU with practices more closely following the organic standards with those involving practices prohibited by organic standards. This allowed for differentiating several groups of LPU through a cluster analysis for later comparison. 
Table 1: Technical-economic indicators used to characterize Livestock Production Units (LPU) in the humid tropics of Chiapas, Mexico

\begin{tabular}{|c|c|}
\hline Technical-economic indicators & Definitions \\
\hline Age of LPU owner (years) & Age of LPU owner \\
\hline Herdsize (AU) & $\begin{array}{l}\text { According to the equation proposed by Scarnecchia and Kothmann (1982), } \\
\text { Animal Units (AU) of each LPU were standardized according to live weight, age and } \\
\text { physiological stage (calf, cow, steer, bull) }\end{array}$ \\
\hline Animal load (AU/ha) & AU raised per hectare of land* \\
\hline Own grassland surface area (ha) & Surface area for grazing that is owned by the farmer \\
\hline Rented grassland surface area (ha) & Surface area for grazing that is rented \\
\hline Total supplement (kg/cow/year) & $\begin{array}{l}\mathrm{Kg} \text { of feed supplement (all feed other than fodder) produced in the LPU plus supplement } \\
\text { purchased from outside the LPU per cow per year }\end{array}$ \\
\hline Birthrate (\%) & $\begin{array}{l}\text { Percentage of young born annually with respect to total number of females fit for } \\
\text { reproduction in the LPU* }\end{array}$ \\
\hline Adult death rate $(\%)$ & $\begin{array}{l}\text { Annual percentage of death of adult cattle (due to illness or accident) with respect to total } \\
\text { number of adults in the LPU* }\end{array}$ \\
\hline Death rate of young $(\%)$ & $\begin{array}{l}\text { Annual percentage of death of young (during lactation) with respect to total number of young } \\
\text { born in the LPU }\end{array}$ \\
\hline Milki & Number of months cows are milked \\
\hline (L/day) & Average liters of milk produced per co \\
\hline Milk produc & Average liters of milk produced per cow per year \\
\hline Annual cattle feed cost $(\%)$ & $\begin{array}{l}\text { LPU's annual percentage of cost in cattle feed with respect to income from sale of meat and } \\
\text { milk }\end{array}$ \\
\hline Cost & Fixed and variable costs of producing $1 \mathrm{~kg}$ of Live Weight (LW) \\
\hline Cost of production of milk (Mexican & Fixed and variable costs of producing $1 \mathrm{~L}$ of milk \\
\hline Cost of production per cow (Mexican 1 & Fixed and variable costs of maintaining a cow in production over 1 year \\
\hline Gross margin per cow (Mexican pes & ross income that the average cow provides to the LPU per year \\
\hline Total net margin per cow (Mexican pesos**/year) & $\begin{array}{l}\text { Difference between gross margin and fixed and variable costs, divided by average } \\
\text { annual number of cows in the LPU over } 1 \text { year; fixed costs include family and hired labor }\end{array}$ \\
\hline Economic efficiency & $\begin{array}{l}\text { Efficiency with which the farmer uses income from sales and subsidies to satisfy the LPU's } \\
\text { needs (fixed and variable costs) }\end{array}$ \\
\hline Dependence on petroleum (\%) & $\begin{array}{l}\text { Percentage of annual spending for petroleum-based inputs (chemical fertilizers, plastics, } \\
\text { non-renewable energy, etc.) }\end{array}$ \\
\hline Feed autonomy $(\%)$ & $\begin{array}{l}\text { Percentage of spending for purchased feed with respect to total feed expense which consists } \\
\text { of feed purchase+grass cultivation and improvement }+ \text { renting of grazing land }\end{array}$ \\
\hline
\end{tabular}

Procedure for obtaining information: Information used to calculate the organic livestock raising conversion index (ICOGAN according to its Spanish initials) was obtained through direct observation as well as a questionnaire applied to the owners of the 50 LPU. The farms of those interviewed are located in the municipal seat of Tecpatan (10) and in the villages of Luis Espinoza (21), Emiliano Zapata (8), El Porvenir (5), Cushaygen (2) and Raudales Malpaso (4).

Characterization of livestock production units: Technical-economic characterization of cattle raising was carried out using quantitative indicators previously defined in other studies (Mena et al., 2012; DelgadoPertinez et al., 2013). These indicators are presented in Table 1.

Evaluation of the potential for converting conventional livestock production units to organic production: The level of organic production of each LPU was evaluated by applying ICOGAN, proposed by Mena-Guerrero et al. (2009) and adapted to the context of Mexican agriculture by Nahed-Tarol et al. (2012). ICOGAN which was developed by consulting twelve researchers in organic livestock raising as well as organic regulations (Mena-Guerrero et al., 2009), consists of 37 variables conforming 10 indicators (Table 2). In order to select variables and indicators, those consulted took into account the following ecological agriculture principles adequate use of permitted, prohibited and restricted substances for preventing, curing and eradicating pests and diseases and efficient use of agroecological technologies that require little capital and allow for optimal use of local resources as well as long-term maintenance of the physical environment, biological diversity and soil productive capacity (Mena-Guerrero et al., 2009; Nahed-Toral et al., 2012).

Table indicators, weighting factors and variables that integrate the organic livestock raising conversion index (ICOGAN) applied to traditional dual purpose cattle farms in the humid tropics of Chiapas, Mexico.

\section{Feeding management (0.12):}

- $\quad$ Feeding of animals only with feed permitted by organic regulations

- Grazing of animals

- At least $60 \%$ of Dry Matter (DM) of daily ration is fibrous fodder

- At least $50 \%$ of feed comes from the same or another ecological farm.

\section{Sustainable grassland management $(0.15)$ :}

- $\quad$ Rotation of pastures

- Appropriate animal load

- Association of fodder crops

- Cultivation of woody fodder crops

- $\quad$ Silvopastoril system 
Table 2: Average value for ICOGAN, range of values (minimum and maximum) of ICOGAN and classification of potential of organic conversion by clusters of livestock production units in the humid tropics of Chiapas, Mexico

\begin{tabular}{lllll}
\hline & Clusters & & & \\
Variables & 1 & 2 & 3 & F-values \\
\hline $\mathrm{n}$ & 17 & 14 & 19 & - \\
Range (\%) ICOGAN & $20.3-48.8$ & $50.3-54.8$ & $56.6-77.7$ & - \\
Average (\%) ICOGAN & $42.6( \pm 7.4)^{\mathrm{a}}$ & $49.9( \pm 2.2)^{\mathrm{b}}$ & $61.5( \pm 5.5)^{\mathrm{c}}$ & 42.8 \\
\hline
\end{tabular}

$\overline{\mathrm{a}, \mathrm{b}, \mathrm{c}}$ Different letters in the same row indicate significant differences $(\mathrm{p}<0.05) ;{ }^{*} \mathrm{~F}$ test: alpha of $95 \%$; ICOGAN: organic livestock raising conversion index

\section{Soil fertilization (0.06):}

- Organic

- Chemical

\section{Weed control in grasses and crops $(0.06)$ :}

- Mechanical

- Chemical

Pest control in grasses and crops (0.06):

- Ecological

- Chemical

Veterinary prevention and care (0.12):

- Application of obligatory vaccines

- Quarantine of introduced and sick animals

- Natural treatment of illnesses

- Use of natural internal anti-parasite medicines

- Use of permitted allopathic internal anti-parasite medicines (maximum twice yearly)

- Use of natural external anti-parasite medicines

\section{Breeds and reproduction (0.06):}

- Farm has only cross-breed animals and/or those adapted to the region

- Animal reproduction is through natural mounting

\section{Animal well-being (0.07):}

- Natural lactation until 8 months of age

- Sufficient space per animal in rooved enclosures and outdoors

- $\quad$ Sufficient feeders and water sources

- Protection of animals from inclement weather (cold, heat, rain and humidity)

- Horns of young animals are cut and those of older animals are trimmed.

\section{Food safety (0.15):}

- Strict hygienic-sanitary control of facilities, equipment and milking and milk management
- Animals are free of brucellosis and tuberculosis

- Animals seropositive to brucellosis and tuberculosis are eliminated

- Animal products are free of antibiotics, hormones and pesticides

\section{Ecological farm management (0.15):}

- Farmer receives training and/or advisory for organic certification

- Farmer has organic transition plan or is certified

- Farmer keeps records of the organic transition process

- Farmer receives incentives for organic production

- Farmer receives a fair constant price for sale of products year round

Variables and calculation of indicator values: The 37 variables that integrate the 10 indicators of ICOGAN (Table 3 ) were coded as binomial $(0,1)$ in order to homogenize the original units of measure and due to the fact that organic regulations are based on specific criteria regarding use of permitted (1) and prohibited (0) inputs and practices. In this manner, each variable acquires a value of its own which is mutually exclusive with the others and has a binomial or Bernoulli distribution (Zar, 1984) which facilitated calculation of the value of each variable. The total value for each indicator is the arithmetic average of the values ( 0 or 1 responses) of its variables (Grimm and Wozniak, 1990). In this manner, the values of the ten indicators were standardized to a relative percentage scale. The optimal value $(100 \%)$ of an unweighted indicator is achieved when the responses of all its variables are positive (coded as 1). A percentage value of each indicator in the LPU was calculated by summing the responses of their variables ( 0 or 1$)$ and multiplying this number by 100 . This index is based on the multi-criteria approach regarding weighting and aggregation of information (Munda et al., 1994; Falconi and Burbano, 2004; Munda, 2004) and is intended to facilitate understanding of technological and environmental limitations and potential of LPU in a specific economic and social context which facilitates farmer decision making, so that, the farm may transition toward organic certification. 
Table 3: Technical-economic indicators of the livestock production units by clusters in the humid tropics of Chiapas, Mexico

\begin{tabular}{lllll}
\hline & Clusters & & & \\
& -1 & & \\
Technical-economic indicators & 1 & 2 & 3 & F, p-values \\
\hline $\mathrm{N}=50$ & 17 & 14 & 19 \\
Age of LPU owner (years) & $58( \pm 12)$ & $51( \pm 13)$ & $56( \pm 19)$ & NS \\
Herdsize (AU) & $65.9( \pm 63.1)^{\mathrm{a}}$ & $51.5( \pm 25.2)^{\mathrm{a}, \mathrm{b}}$ & $34.9( \pm 18.3)^{\mathrm{b}}$ & $4.46,0.017$ \\
Animal load (AU/ha) & $1.57( \pm 1.1)^{\mathrm{a}}$ & $1.21( \pm .4)^{\mathrm{a}, \mathrm{b}}$ & $1( \pm .4)^{\mathrm{b}}$ & $4.42,0.017$ \\
Own grassland surface area (ha) & $29.9( \pm 19.9)$ & $33.9( \pm 19.1)$ & $34.5( \pm 19.7)$ & $\mathrm{NS}$ \\
Rented grassland surface area (ha) & $18.2( \pm 29.2)$ & $5.6( \pm 7.8)$ & $3.6( \pm 8.8)$ & $\mathrm{NS}$ \\
Total supplement (kg/cow/year) & $1367.9( \pm 2471.8)^{\mathrm{a}}$ & $1064.4( \pm 1288.5)^{\mathrm{a}}$ & $209.9( \pm 428.6)^{\mathrm{b}}$ & $3.23,0.48$ \\
Birthrate (\%) & $81( \pm 36)$ & $90( \pm 35)$ & $85( \pm 33)$ & $\mathrm{NS}$ \\
Adult death rate (\%) & $2.9( \pm 2.9)$ & $2.6( \pm 3.1)$ & $2.5( \pm 6.3)$ & $\mathrm{NS}$ \\
Death rate of young (\%) & $13.6( \pm 9.4)$ & $9.1( \pm 7.3)$ & $9.5( \pm 12.6)$ & $\mathrm{NS}$ \\
Milking (months) & $8.0( \pm 1.4)$ & $7.9( \pm 1.0)$ & $8.2( \pm 1.7)$ & $\mathrm{NS}$ \\
Milk production (L/day) & $6.0( \pm 2.7)$ & $5.0( \pm 2.1)$ & $4.5( \pm 2.3)$ & $\mathrm{NS}$ \\
Milk production (L/year) & $794.9( \pm 589.0)$ & $742.0( \pm 310.6)$ & $666.8( \pm 410.9)$ & $\mathrm{NS}$ \\
Annual cattle feed cost (\%) & $34.1( \pm 43.5)^{\mathrm{a}}$ & $17.9( \pm 17.7)^{\mathrm{ab}}$ & $6.1( \pm 9.1)^{\mathrm{b}}$ & $4.92,0.011$ \\
Cost of production per kg LW (Mexican pesos/kg) & $69.19( \pm 39.9)^{\mathrm{a}}$ & $49.8( \pm 11.8)^{\mathrm{a}, \mathrm{b}}$ & $37.2( \pm 18.1)^{\mathrm{b}}$ & $6.55,0.003$ \\
Cost of production of milk (Mexican pesos**/L) & $12.0( \pm 3.1)^{\mathrm{a}}$ & $12.4( \pm 3.9)^{\mathrm{b}}$ & $8.9( \pm 2.9)^{\mathrm{b}}$ & $5.79,0.006$ \\
Cost of production per cow (Mexican pesos**/year) & $13891.7( \pm 7704.5)^{\mathrm{a}}$ & $11684.0( \pm 4624.2)^{\mathrm{a}, \mathrm{b}}$ & $8476.1( \pm 5140.6)^{\mathrm{b}}$ & $3.38,0.032$ \\
Gross margin per cow (Mexican pesos**/year) & $15345.7( \pm 70001.3)$ & $14373.1( \pm 4396.8)$ & $15949.7( \pm 8186.4)$ & $\mathrm{NS}$ \\
Total net margin per cow (Mexican pesos**/year) & $1454.0( \pm 39.24 .6)^{\mathrm{a}}$ & $2689.1( \pm 3580.4)^{\mathrm{a}}$ & $7473.6( \pm 5248.2)^{\mathrm{b}}$ & $9.38 ; .000$ \\
Economic efficiency & $1.2( \pm .4)^{\mathrm{a}}$ & $1.3( \pm .4)^{\mathrm{a}}$ & $2.0( \pm .7)^{\mathrm{b}}$ & $11.07,0.000$ \\
Dependence on petroleum (\%) & $8.4( \pm 6.1)^{\mathrm{ab}}$ & $13.7( \pm 8.3)^{\mathrm{b}}$ & $4.6( \pm 4.9)^{\mathrm{a}}$ & $7.56,0.001$ \\
Feed autonomy (\%) & $22.6( \pm 34.0)$ & $18.1( \pm 31.9)$ & $38.3( \pm 42.9)$ & $\mathrm{NS}$ \\
\hline
\end{tabular}

${ }_{\mathrm{a}, \mathrm{b}, \mathrm{c}}$ Different letters in the same row indicate significant differences $(\mathrm{p}<0.05)$; NS: Non-significant; F-test: alpha of $95 \%$; AU: Animal unit; * Data refers to AU in the LPU when the questionnaire was applied; **Exchange rate of Mexican pesos to US dollars as of March 05, 2019 was 19.97

Weighting of indicators: The coefficient for weighting each indicator (Table 3) was based on the importance of each indicator to the principles of agroecology and organic livestock raising and the difficulty of eliminating or substituting use of inputs or practices prohibited by organic regulations. The weighted value of each indicator was obtained by multiplying the arithmetic average of the values of its variables by its specific weighting factor. A sensitivity analysis of weighting coefficients for each predetermined indicator of ICOGAN influenced the results; the influence of the coefficient depends on the responses obtained for the variables that integrate each of the indicators. Furthermore, in order to facilitate interpretation and discussion of results, we classified the values of the indicators, their variables and ICOGAN as a whole into five categories of potential for organic conversion; very low $(0-20 \%)$, low $(21-40 \%)$ intermediate (41-60\%), high (61-80\%) and very high (81$100 \%)$.

Systematization and analysis of information: Data obtained from the 50 LPU sampled was systematized in two Excel databases-one for the technical-economic indicators and the other for ICOGAN. First, a hierarchical cluster Classification (C) was carried out with the furthest neighbor method where the grouping factor was the series of data of the weighted ICOGAN of the 50 LPU. This classification allowed for analyzing by groups each technical-economic indicator, the ten indicators making up ICOGAN and ICOGAN as a whole. Secondly, a Kolmogorov-Smirnov normality test was applied to the indicators (Grimm and Wozniak, 1990). Results indicated that data should be transformed to approach the normal distribution through its natural logarithm or arcsine (according to the nature of the data) in order to be able to carry out a comparison of the means through Analysis of Variance (ANOVA). The results of the indicators whose average values differed significantly among groups in the ANOVA test were submitted to a posteriori contrasts (multiple comparisons) through Tukey's HSD or the Games-Howell method (depending on the homogeneity of variances test). All statistical analyses were carried out using Version 15 of the SPSS statistical package (Mehta and Patel, 2011).

\section{RESULTS AND DISCUSSION}

Cluster analysis: A cluster analysis allowed for identifying three clearly differentiated groups of LPU $(p<0.05)$ with different values for ICOGAN (Fig. 1). We attempted to achieve an equal number of repetitions (or LPU) in each cluster $(\mathrm{p}<0.05)$. The LPU of $\mathrm{C} 1$ had the lowest values-indicating low potential for organic conversion and those of $\mathrm{C} 3$ had the highest-indicating high potential (Table 4). This grouping allowed for planning agroecological technologies for each group of farmers which may help them overcome their limitations. In another study by Nahed-Toral et al. (2013), organic certification of milk and of animals sold live for meat has been achieved after overcoming limitations identified through ICOGAN. The objective of ICOGAN is for 
Table 4: Indicators and values of ICOGAN of livestock production units grouped by clusters in the humid tropics of Chiapas, Mexico

\begin{tabular}{|c|c|c|c|c|}
\hline \multirow[b]{2}{*}{ ICOGAN/Indicators } & \multicolumn{3}{|l|}{ Clusters } & \multirow[b]{2}{*}{ F, p-values } \\
\hline & 1 & 2 & 3 & \\
\hline Feeding management & $67.5( \pm 31.6)^{\mathrm{a}}$ & $80.4( \pm 10.6)^{\mathrm{ab}}$ & $96.1( \pm 9.4)^{\mathrm{b}}$ & $9.0,0.000$ \\
\hline Sustainable grassland management & $36.5( \pm 12.2)^{\mathrm{a}}$ & $47.1( \pm 9.9)^{b}$ & $53.7( \pm 13.4)^{\mathrm{b}}$ & $9.0,0.000$ \\
\hline Soil fertilization & $88.2( \pm 33.2)$ & $92.8( \pm 26.7)$ & $100.0( \pm 0.0)$ & NS \\
\hline Weed control in grasses and crops & $47.1( \pm 51.4)^{\mathrm{a}}$ & $71.4( \pm 46.9)^{\mathrm{ab}}$ & $94.7( \pm 22.9)^{\mathrm{b}}$ & $5.9,0.005$ \\
\hline Pest control in grasses and crops & $64.7( \pm 49.2)$ & $85.7( \pm 36.3)$ & $94.7( \pm 22.9)$ & NS \\
\hline Veterinary prevention and care & $27.3( \pm 14.2)^{\mathrm{a}}$ & $36.7( \pm 11.7)^{\mathrm{a}}$ & $49.8( \pm 18.0)^{\mathrm{b}}$ & $9.9,0.000$ \\
\hline Breeds and reproduction & $97.1( \pm 12.1)$ & $96.4( \pm 13.4)$ & 100 & NS \\
\hline Animal well-being & $67.1( \pm 9.8)$ & $65.7( \pm 9.4)$ & $68.4( \pm 15.4)$ & NS \\
\hline Food safety & $40.4( \pm 21.8)^{\mathrm{a}}$ & $57.4( \pm 15.9)^{\mathrm{b}}$ & $66.7( \pm 17.1)^{b}$ & $9.1,0.000$ \\
\hline Ecological farm management & $8.2( \pm 10.1)^{\mathrm{a}}$ & $5.7( \pm 9.4)^{\mathrm{a}}$ & $22.1( \pm 14.1)^{\mathrm{b}}$ & $6.3,0.004$ \\
\hline ICOGAN & $42.6( \pm 7.4)^{\mathrm{a}}$ & $49.9( \pm 2.2)^{\mathrm{b}}$ & $61.5( \pm 5.5)^{\mathrm{c}}$ & $51.8,0.000$ \\
\hline
\end{tabular}

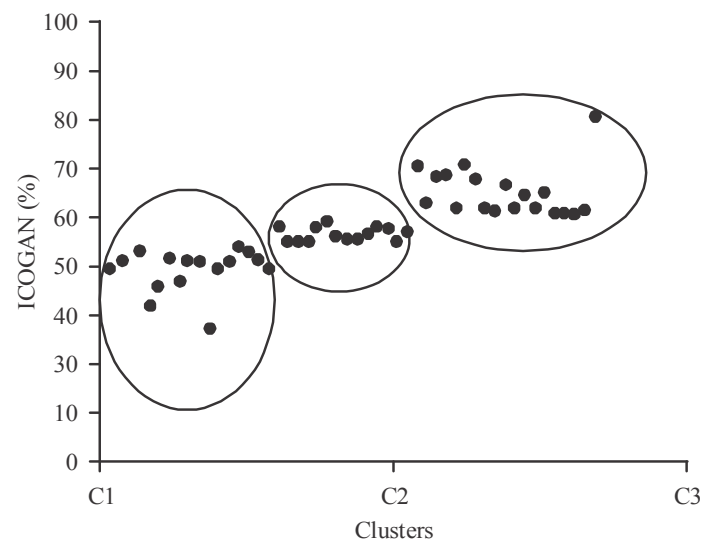

Fig. 1: Clusters (C) of the organic livestock raising conversion index (ICOGAN) of livestock production units in the humid tropics of Chiapas, Mexico

conventional LPU to be capable of sustaining themselves over time, and to modify themselves when conditions demand. For ecological and social resources and processes involved in LPU to be capable of continuing to function, they must be capable of self-regulation, coordination, reorganization and adapting themselves in the face of internal and external changes (Nahed et al., 2006).

Context of cattle raising in the study area: In the study area, the predominant agrosilvopastoral dual purpose cattle raising system has produced milk and weaned calves for sale for five decades (NahedToral et al., 2012). This system follows traditional practices with few external inputs, uses a wide variety of types of vegetation in an integrated manner and follows a management calendar adapted to seasonal variability. Cattle raising is integrated with crop production and forestry through energy flows and circulation of materials by fertilizing crops with manure, feeding cattle with agricultural waste and grazing them in areas with a tree gradient consisting of one or more of the following: treeless grassland; grassland with living fences, shrubs and/or fallows; dispersed trees and forested areas, used in an alternating manner over the course of the annual cycle.

In general, there is a tendency for the technical-economic indicators of $\mathrm{C} 1$ to have the lowest values and those of $\mathrm{C} 3$ to have the highest. Owners of the LPU evaluated have an average age of 55 which is a disadvantage for developing agrosilvopastoral systems and organic livestock raising in the region given that older adults show less openness to receiving training or advisory and are less interested in adopting technological innovations. Surface area of grassland owned by the farmers ranged from 29.9-34.5 ha while that of rented grassland ranged from 3.6-18.2 ha. All LPU have cattle of the breed Zebu Bos indicus and of a mixed-breed biotype, both of which are crossed with some European breeds (Bos Taurus) particularly Swiss and Holstein and to a lesser extent Simmental. In the majority of LPU (97\%), cows are milked manually once daily, stimulating milk flow by allowing the calf to suckle 2-3 min before milking (Nahed-Toral et al., 2012). This milking technique is commonly used in the Mexican tropics and has been previously described by Ortiz (1982).

In all LPU, the breeding bull is continually with the cows and therefore, siring occurs through natural direct mounting. For this reason, calves may be born any time of year. Weaning occurs naturally between 7 and 8 months of age at an average weight of $207.5 \mathrm{~kg}$ ( \pm 9.6$)$. All calves are sold upon weaning to be fattened in other regions of Mexico, principally in central or Northern Mexico. Sale of milk, weaned calves and discarded cows to intermediaries is farmer's principle source of income. Involvement of intermediaries in marketing as in other regions of the Mexican tropics and in other regions of the world seriously limits the sale price for live animals and animal products. 
Herd size was greatest in $\mathrm{C} 1$ and smallest in $\mathrm{C} 3$ $(p<0.05)$. A similar tendency $(p<0.05)$ was observed for animal load and surface area of rented grassland $(p>0.05)$ and an inverse tendency $(p>0.05)$ for surface area of owned grassland. LPU (principally those of $\mathrm{C} 1$ ) rent grasslands during the dry season in order to prevent excessive trampling and overgrazing of the little land they have. Given insufficient surface area for grazing in LPU of $\mathrm{C} 1$, these farms have a greater animal load in their grasslands than do those of $\mathrm{C} 2$ and $\mathrm{C} 3$; nevertheless, all three $\mathrm{C}$ are within the limit of two AU per hectare stipulated by organic regulations (IFOAM., 2018).

One principle difference among the three $\mathrm{C}$ is feed supplementation: up to 6.5 times more mineral feed supplements such as salts are provided by $\mathrm{C} 1$ and $\mathrm{C} 2$ farmers at free access, mixed with energy supplements (for example, molasses, maize kernels and maize pericarp) and/or protein supplements (for example, chicken manure and feed concentrates) as compared to that provided by $\mathrm{C} 3$ farmers $(209.9 \mathrm{~kg}$ per cow per year; $\mathrm{p}<0.05$ ) which is similar to that reported by Orantes-Zebadua et al. for the same study area (1-3 kg of supplement per cow per day).

A high birth rate is observed for all three $\mathrm{C}$, varying from $81.0-90.0 \%$ which is greater than that reported by Nahed-Toral et al. (2013) for Mazapa, Chiapas (67\%), Huitiupan, Chiapas (61\%), Tacotalpa, Tabasco (72.4\%) and Tecpatan, Chiapas (72.8\%). The death rate for adult animals was low, varying from 2.5-2.9\% which approximates values of 2.6-5.1\% reported by Nahed-Toral et al. (2013) for the same area while the death rate for young animals was relatively high, varying from $9.1-13.6 \%$ for the three $\mathrm{C}(>0.05)$ which is greater than rates reported by Nahed-Toral et al. (2013) $5.3-7.3 \%$.

Number of months of milking per year, milk production per cow per day, and milk production per cow per year did not statistically differ among $\mathrm{C}$. For the same study area, Orantes-Zebadua et al. report a daily milk production level per cow $(4.4 \pm 1.8 \mathrm{~L})$ which is very similar to that of $\mathrm{C} 3(4.5 \pm 2.3 \mathrm{~L})$. Meanwhile, for the same study area, Nahed et al. (2018) report annual milk production values which are greater $(1183 \pm 4.3 \mathrm{~L})$ than those estimated in the present study.

Farmer's annual feed cost with respect to income from sale of meat and milk was greatest $(\mathrm{p}<0.05)$ in $\mathrm{C} 1$ and lowest in $\mathrm{C} 3$. Cost of production per $\mathrm{kg}$ of meat and per $\mathrm{L}$ of milk varied $(\mathrm{p}<0.05)$ among $\mathrm{C}$ and production costs of both products were highest for $\mathrm{C} 1$ and lowest for C3. Similarly, cost of production per cow was greatest $(p<0.05)$ in $\mathrm{C} 1$ and lowest in C3. Gross margin per cow did not vary ( $>0.05$ ) among $C$; nevertheless, net margin (income) per cow per year was greatest $(\mathrm{p}<0.05)$ in $\mathrm{C} 3$ (\$7473.6 $\$ 5248.2)$.

Low levels of production of animals and animal products and high costs of production lead to LPU's net margin of income-principally those of C1-being very low. Zepeda-Cancino et al. indicate that in the study area, lack of income aside from livestock raising as well as marketing problems such as low milk prices with respect to cost of production (which includes family labor) as well as sale of animals to intermediaries discourages farmers as they are barely able to satisfy their basic needs with the exception of those farmers that have another income source. Therefore, younger generations tend to lose interest in farming and continuity of LPU may be reduced.

Results of economic efficiency (considering subsidies and family labor) indicate that the LPU of $\mathrm{C} 3$ are more efficient $(\mathrm{p}<0.05)$ than those of $\mathrm{C} 2$ and $\mathrm{C} 1$. For the indicators related to cost of production, especially, "dependence on petroleum" and "cost of production per cow"-C3 has notably lower costs, principally due to low purchase of external inputs and little use of machinery which leads to less contamination. Meanwhile, the level of feed autonomy was similar among LPU of all three C ( $>0.05$ ), although, $\mathrm{C} 3 \mathrm{had}$ a somewhat greater level due to a lower percentage of total annual farm costs in purchase of feed $(p>0.05$; Table 4$)$.

Evaluation of viability of organic conversion of LPU: Table 4 shows average percentages of approximation to the organic model for the ten indicators of ICOGAN and for ICOGAN as a whole for the LPU grouped by C. The values of all indicators for $\mathrm{C} 3$ are significantly greater $(p<0.05)$ or greater to a non-significant level $(p>0.05)$ than the values of $\mathrm{C} 1$ and $\mathrm{C} 2$. With the exception of the indicator "ecological farm management" which shows very low potential of organic conversion, the rest of C3's indicators show intermediate to very high potential of conversion. $\mathrm{C} 2$ has significantly greater values than $\mathrm{C} 1$ $(p<0.05)$ for the indicators "sustainable grassland management" and "food safety" while "feeding management", "soil fertilization", "weed control in grasses and crops", "pest control in grasses and crops", and "veterinary prevention and care" were greater to a non-significant level for $\mathrm{C} 2$ than for $\mathrm{C} 1 \quad(\mathrm{p}>0.05)$, although, the values of these seven indicators vary greatly, showing that the potential for organic conversion varies for different aspects of farm management. $\mathrm{C} 1$ has higher values at non-significant levels than $\mathrm{C} 2(\mathrm{p}>0.05)$ for the indicators "breed and reproduction", "animal well-being" and "ecological farm management". For these two clusters, these indicators vary greatly with respect to their potential for organic conversion. The five indicators that show high to very high potential for conversion for all three C are "feeding management", "weed control in grasses and crops", "pest control in grasses and crops", "breed and reproduction" and "animal well-being".

The values of ICOGAN as a whole are different for each of the three $\mathrm{C}(\mathrm{p}<0.05)$; $\mathrm{C} 3$ has the highest potential for organic conversion followed by $\mathrm{C} 2$ and finally, $\mathrm{C} 1$. 
These results indicate that potential for organic conversion of the three $\mathrm{C}$ of the LPU evaluated ranges from low to intermediate-similar to that reported by Nahed-Toral et al. (2013) where after extensive training to overcome limitations of their LPU, farmers achieved organic certification which has allowed them to increase the demand for their products and consequently their prices and in general their LPU have become more sustainable.

Feeding management: The variables for the indicator "feeding management" show very high potential for organic conversion for C3 $(84.2-100 \%)$ and for C2 $(100 \%)$, except for the variable feeding of animals only with feed permitted by organic regulations which has low potential for $\mathrm{C} 2(21.4 \%)$. The variables of $\mathrm{C} 1$ show high to very high potential for organic conversion (70.6-94.1\%) with the exception of feeding of animals only with feed permitted by organic regulations which has low potential $(29.4 \%)$. The most significant strength regarding feeding in the LPU evaluated is that it is based on grazing and the factor which most limits the potential for organic conversion for some LPU is use of commercial feed, chicken manure and/or chemical feed additives these should be substituted by permitted feed and farms should assure that purchased grains and fodder come from other ecological farms.

Sustainable grassland management: For the indicator "sustainable grassland management", the LPU of all three $\mathrm{C}$ have a very high potential for organic conversion $(88.2-100 \%)$ for the variables pasture rotation and appropriate animal load. Meanwhile, in all three Cs, the variables association of fodder crops and silvopastoral systems show very low viability of conversion $(\mathrm{C} 1$ and $\mathrm{C} 2=0.0 \%$ for both variables and $\mathrm{C} 3=5.3$ and $10.5 \%$ for the two variables) while the variable cultivation of woody fodder crops ranges from very low to intermediate $(\mathrm{C} 1=5.9, \mathrm{C} 2=35.7$ and $\mathrm{C} 3=52.6 \%)$. In order to achieve sustainable grassland management, there is a need to improve the above-mentioned variables, associate leguminous species in any pastures in which grains are currently planted as monocultures and plant in different spatial arrangements local woody fodder crops such as Erytrinaspp, Gliricidia sepium and Leucaena leucocephala. Such diversified pastures protect biodiversity and provide greater soil protection as well as environmental services such as carbon capture, reduction in $\mathrm{CH}_{4}$ and $\mathrm{N}_{2} \mathrm{O}$ emissions and mitigation of climate change (Jose, 2009).

Soil fertilization: For the indicator "soil fertilization", all LPU of all three $\mathrm{C}$ show very high viability of conversion to the organic model $(\mathrm{C} 1=88.2, \mathrm{C} 2=92.8$ and $\mathrm{C} 3=100 \%$ ). These high values are due to the fact that use of chemical fertilizers in grasslands is minimal; rather, nutrients are contributed to the soil only by cattle depositing manure during grazing. However, in the majority of the LPU evaluated, manure accumulated by cattle in stables is not processed into organic fertilizer (for example, compost, bocashi, vermiculture, biofertilizers or biofermentation) and green manures or cover crops are not used to fertilize grasslands, as suggested by CERTIMEX (200) and IFOAM (2018).

Weed control in grasses and crops: For the indicator "weed control in grasses and crops", the LPU of all three $\mathrm{C}$ have intermediate to very high viability of organic conversion $(\mathrm{C} 1=47.0, \mathrm{C} 2=71.4$ and $\mathrm{C} 3=94.7 \%)$. This is due to the fact that the majority of farmers control weeds manually rather than using chemical herbicides. Rather than completely eradicating weeds, ecological weed control involves maintaining populations of spontaneously growing plant species in pastures and crops at levels by which interspecies competition does not reduce productivity of grasses.

Pest control in grasses and crops: With respect to the indicator "pest control in grasses and fodder crops", the LPU of all three $\mathrm{C}$ have high to very high potential for organic conversion $(\mathrm{C} 1=64.7, \mathrm{C} 2=85.7$ and $\mathrm{C} 3=94.7 \%$ ). This is due to the fact that farmers do not use chemical pesticides to control insects in their grasslands. Rather, control is principally manual and to a lesser extent mechanical through grazing. Use of botanical insecticides and repellents (Cook et al., 2007) as well as integrated pest management which includes ecological soil and biodiversity management (Von Borell and Sorensen, 2004) could improve efficiency of pest and disease control.

Veterinary prevention and care: With respect to the indicator "veterinary prevention and care", the LPU of the three $\mathrm{C}$ have low to intermediate potential for organic conversion (Table 3). Values for the variables of this indicator range from very low to very high; application of obligatory vaccines such as brucellosis and paralytic rabies $(\mathrm{C} 1=70.6, \mathrm{C} 2=92.9$ and $\mathrm{C} 3=100 \%)$; quarantine of introduced and sick animals $(\mathrm{C} 1=52.9, \mathrm{C} 2=71.4)$ and $\mathrm{C} 3=89.5 \%)$; natural treatment of illnesses $(\mathrm{C} 1=0.0$, $\mathrm{C} 2=7.1$ and $\mathrm{C} 3=89.5 \%$ ) use of natural internal anti-parasite medicines $(\mathrm{C} 1=0.0, \mathrm{C} 2=0.0$ and $\mathrm{C} 3=$ $10.5 \%$ ) use of permitted allopathic internal anti-parasite medicines $(\mathrm{C} 1=41.2, \mathrm{C} 2=42.8$ and $\mathrm{C} 3=78.9 \%)$ and use of natural external anti-parasite medicines $(\mathrm{C} 1=0.0, \mathrm{C} 2=7.1$ and $\mathrm{C} 3=15.8 \%)$. Some farmers do not administer internal anti-parasite medicines, others administer more than the two permitted by organic 
regulations per year and the majority sporadically use antibiotics following organic regulations to treat infections in their animals. Raising creole breeds and their crosses, adequate nutrition, preventative measures that favor resistance to climatic factors and diseases and substitution of antibiotics and anti-parasite medicines with natural methods such as homeopathy, herbalism and acupuncture would help to improve this indicator (Mena-Guerrero et al., 2009).

Breeds and reproduction: The variables for the indicator "breeds and reproduction" show very high potential for organic conversion (92.8-100\%), due to the fact that over $75 \%$ of bovines are cross-breeds that are adapted to the region. In the large majority of LPU of all three C, animals reproduce through direct mounting. Adaptation of the animals to local climatic conditions and traditional management techniques varies from low to high as reflected by the high values for the technical-economic indicator birth rate $(\mathrm{C} 1=81.0, \mathrm{C} 2=90.0$ and $\mathrm{C} 3=$ $85.0 \%$ ) while the technical-economic indicator death rate of young is relatively high $(\mathrm{C} 1=13.6, \mathrm{C} 2=9.2$ and $\mathrm{C} 3=$ $9.6 \%)$, although, adult death rate is low $(\mathrm{C} 1=2.9, \mathrm{C} 2=$ 2.6 and $\mathrm{C} 3=2.5 \%$ ). Although, organic regulations permit artificial insemination, in the majority of the LPU mounting is direct and continuous as are oestrus of females and births which avoids use of chemical hormones. Farms would benefit by having breeding bulls of mixed breeds adapted to local conditions in order to develop resistance to diseases and parasites (Nauta et al., 2006; Von Borell and Sorensen, 2004; Hersleth et al., 2012).

Animal well-being: The indicator "animal well-being" shows very high potential for organic conversion $(100 \%)$ for the variables natural lactation until 8 months of age and sufficient feeders and water sources. This is followed by horns of young animals are cut and those of older animals are trimmed which shows high to very high potential for conversion $(\mathrm{C} 1=94, \mathrm{C} 2=85.7$ and $\mathrm{C} 3=$ $73.7 \%$ ), followed by sufficient space per animal in rooved enclosures and outdoors which shows low to intermediate viability $(\mathrm{C} 1=23.5, \mathrm{C} 2=28.6$ and $\mathrm{C} 3=52.6 \%)$ and protection of animals from inclement weather (cold, heat, rain and humidity) which shows very low potential $(\mathrm{C} 1=$ $17.6, \mathrm{C} 2=14.3$ and $\mathrm{C} 3=15.8 \%$ ). In general, for all three $\mathrm{C}$ the latter two variables should be improved to provide optimal conditions, so that, animals develop their functions of lactation, growth, reproduction and production and are able to comfortably satisfy their biological needs (Vasta et al., 2012).

Food safety: The variables for the indicator "food safety" that show high to very high potential for organic conversion are animals are free of brucellosis and tuberculosis $(\mathrm{C} 1=67.6, \mathrm{C} 2=89.3$ and $\mathrm{C} 3=89.5 \%)$ and animals seropositive to brucellosis and tuberculosis are eliminated $(\mathrm{C} 1=76.5, \mathrm{C} 2=100$ and $\mathrm{C} 3=100 \%)$. However, some animals still prove to be seropositive in local disease diagnosis and vaccination campaigns. Values for the variable animal products are free of antibiotics, hormones and pesticides range from very low to high $(\mathrm{C} 1=17.6, \mathrm{C} 2=33.3$ and $\mathrm{C} 3=66.7 \%)$, indicating highly varying levels of potential for conversion. Few LPU have strict hygienic-sanitary control of facilities, equipment and milking and milk management and therefore, they have very low viability of conversion for this variable $(\mathrm{C} 1=0.0, \mathrm{C} 2=7.1$ and $\mathrm{C} 3=10.5 \%)$. As evidence of "safety of animal products (milk, cheese and meat)" is the guarantee of quality that farmers offer to consumers, the low levels of this indicator provide an obstacle to fulfilling organic standards for all three C, although, principally for $\mathrm{C} 1$ and $\mathrm{C} 2$. Therefore, there is a need to implement strict hygienic-sanitary control of infrastructure and use management practices that avoid chemical substances such as hormones prohibited by organic standards as well as physical contaminants (pieces of metal and other garbage). Strict hygienic-sanitary control, together with organoleptic traits (flavor, aroma, color) and nutritional quality indicate sanitary and nutritional quality of food and promote consumer confidence (Escribano, 2016). Finally, pasture-based feeding has become important to consumers who consider meat from animals raised in such conditions to be more natural and less contaminated and that such practices show greater respect for animal well-being.

Ecological farm management: For the indicator "ecological farm management", the only variable with intermediate to high potential for organic conversion is farmer receives training and/or advisory for organic certification. The other four variables indicate very low viability $(0-22 \%)$. This is due to the fact that farmers have not been trained to improve their farms with respect to the five variables that determine this indicator. Therefore, they should receive training and advisory for transitioning to organic production. There is also a need to keep records of feeding, disease and treatment, production, processing and marketing (Escribano, 2016). Aside from farmer management, government agencies and NGOs should provide incentives for improving quality. The existence of fair, constant prices throughout the year for sale of products would motivate farmers to continue to improve their LPU though sustainable techniques (Hersleth et al., 2012; Nahed-Toral et al., 2012) while also allowing them to reproduce their traditional way of life. The greater net margin and the greater economic efficiency of LPU of C3 and $\mathrm{C} 2$ allow for greater economic reinvestment in the farms in order to carry out modifications which are necessary for achieving organic certification. 


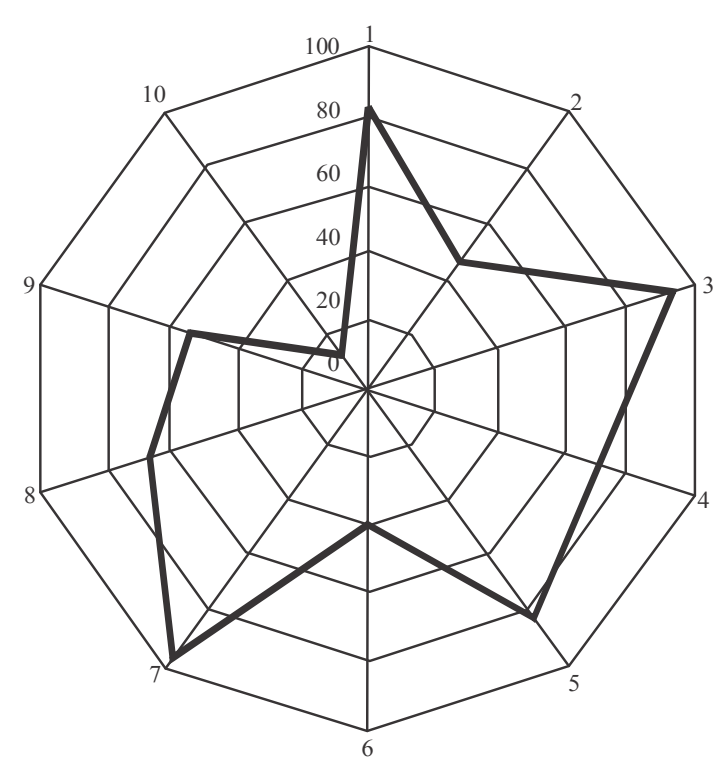

Fig. 2: Summary of indicators that limit and favor organic conversion, regardless of the cluster to which livestock raising units belong: (1) Feeding management, (2) Sustainable grassland management (3) Soil fertilization, (4) Weed control in grasses and crops, (5) Pest control in grasses and crops, (6)Veterinary prevention and care, (7) Breeds and reproduction, (8) Animal well-being, (9) Food safety (10) Ecological farm management

Limitations and potentials of organic conversion of conventional cattle raising: Evaluating the potential for conversion of conventional cattle raising to the organic production model provides an opportunity to identify limitations, potentials (Fig. 2) and opportunities for promoting sustainable livestock raising (Nahed-Toral et al., 2012, 2013). Those ICOGAN indicators with limited potential for organic conversion of the LPU evaluated are "sustainable grassland management" (for $\mathrm{C} 1$ and $\mathrm{C} 2$ ), "soil fertilization" (C1 and $\mathrm{C} 2)$, "weed control in grasses and Crops" (C1), "veterinary prevention and care" (C1 and $\mathrm{C} 2)$, "food safety" ( $\mathrm{C} 1$ and $\mathrm{C} 2)$ and "ecological farm management" (all Cs). While C3 had values above 50\% for all of these indicators except "ecological farm management", $\mathrm{C} 1$ and $\mathrm{C} 2$ have low values for these indicators principally due to the fact that farmers have not received the necessary training and advisory to be able to adhere to the organic regulations, despite the fact that the majority of LPU use traditional agricultural methods and few external inputs. Nevertheless, some indicators show potential viability of organic conversion of the LPU including "feeding management", "pest control in grasses and crops", "breeds and reproduction" and "animal well-being", all of which showed viability for all three C as well as "weed control in grasses and crops" for $\mathrm{C} 2$ and C3 and "food safety" for C3. The LPU of C3 show the greatest potential for organic conversion $(61.5 \%)$, given that all indicators except for "ecological farm management" have intermediate to very high potential for conversion due to the high values of their variables. In summary, the values of ICOGAN range from intermediate to high. The values of ICOGAN found in this study are greater than those found for conventional livestock raising in the Frailesca and Marques de Comillas regions of Chiapas $48.0 \%$ and $53.3 \%$, respectively which showed intermediate levels of viability.

In general, the level of approximation of the LPU evaluated to the organic model is a result of traditional management with low use of external inputs more than implementation of sustainable production technologies. If farmers modify their current form of production, so that, it concords with organic production standards, they will have to wait for the necessary transition or conversion period to elapse in order to reduce to a minimum the residual effects of any agrochemicals previously used. Also, there is a need to train farmers to substitute capital-dependent technologies which degrade the environment with others that make efficient use of local resources, thereby allowing for maintenance of biological diversity and soil productive capacity (Mena-Guerrero et al., 2009; Nahed-Toral et al., 2013). In order to achieve sustainability of the LPU, farmers should review and follow the list of substances permitted, prohibited and restricted by organic regulations (Muller-Lindenlauf et al., 2010).

Transition toward organic production: The transition period for a farm to be considered organic depends on the initial situation or base line; according to IFOAM (2018) this transition period ranges from 12-48 months. Farmers will be more likely to be able to transition to the organic model within the established period, if they are able to improve their farms with respect to the technical-economic and ICOGAN indicators for which they rated lowest, particularly with respect to, diversity of grazing units, use of local resources or those adapted to local conditions and knowledge of natural cycles, low use of external inputs and use of traditional agricultural technologies, artisanal quality of animal products, product quality control, lack of strategic alliances that foment transitioning to organic production and lack of consolidated productive chains that allow farmers to more directly market their products without involvement of intermediaries. These limitations currently impede LPU from marketing animal products in organic markets, significantly limiting prices and making it difficult to achieve sustainability (Nahed et al., 2018). Furthermore, there is a need for decision makers to foment public policy which supports organic livestock production. 
The importance of producing high quality animal products principally lies in their effect on health of consumers who increasingly demand food safety and environmental friendliness. Given consumer interest in recent years in safe, healthy, environmentally friendly food, certification of ecological animal products allows for competing with conventional animal products produced either in intensive or extensive systems. Additionally, certifying their products provides farmers with more opportunities to receive government economic incentives and support for infrastructure, both of which are necessary in the study region.

There is a need for public policy to provide financial support mechanisms, training and advisory; support organizational and management processes throughout the productive chain and implement an organic cattle raising development strategy (Nahed-Toral et al., 2013) which includes a policy of agrifood health and safety that allows for financing organic certification costs in order to differentiate organic and conventional products implementation of government and non-governmental incentives that motivate farmers to adopt environmental friendly technologies including those which reduce greenhouse gas emissions which includes improved feeding practices that promote greater digestibility, thereby reducing emissions of enteric methane as well as improvement of animal health to produce more meat and milk with fewer animals and permanent support by researchers, government agencies and NGOs to develop alliances among actors farmers, marketers, processors and salespeople as well as promotion of animal products in local, national and international markets.

In this manner, meat, milk and cheese produced in the LPU evaluated as well as in the study region in general, may be certified as organic or otherwise of high quality to be able to be marketed in alternative market niches and benefit producers and consumers with which knowledge of product origin would contribute to farm familie's food security, biological and social reproduction of the LPU and environmental sustainability (Nahed et al., 2018).

Fomenting organic cattle raising in the study region: Throughout the municipality of Tecpatan, organic livestock raising is a viable alternative due to the fact that for over 40 years, traditional farming methods which use few external inputs and approximate organic livestock raising practices have contributed to farm families achieving food security (Nahed-Toral et al., 2010; Nahed et al., 2018). The present study shows that the municipality of Tecpatan, inhabited principally by the Zoque ethnic group, presents favorable socioeconomic, technical and environmental conditions for fomenting organic livestock raising. With respect to socioeconomic conditions, the large number of peasants and other small-scale farmers that raise livestock who vary with respect to their level of organization and willingness to convert to ecological cattle raising-may join the market niche of organic livestock raising and obtain greater income and other benefits which allow for improving their living conditions. In this manner, the LPU may continue their biological and social reproduction. With respect to cattle raising practices in this region, current forms of feeding management, soil fertilization, pest control in grasses and crops and livestock breeds and reproduction may also favor sustainable livestock raising. Finally, the region's severe environmental deterioration which has principally resulted from unsustainable agricultural practices justifies fomenting conversion of conventional cattle raising to organics.

Organic livestock raising is based on the principles of clean production and involves strategies that prevent contamination and contribute to provision of environmental services. For example, use of external inputs-such as chemical fertilizers and pesticides as well as fossil fuels-is minimal or absent. Organic LPUs include woody fodder shrubs and trees; grasses are planted in association with leguminous crops; animals used are cross-breeds or those adapted to the region and animals are grazed and provided with a significant proportion of fibrous fodder (Hersleth et al., 2012). These measures generally, allow the LPU to avoid levels of greenhouse gases (nitrous oxide, methane and carbon dioxide) which exceed the system's capacity to absorb them. Furthermore, waste generation is minimized through maximum use of local resources, whereby inputs to the LPU are principally products of on-farm biological processes rather than fossil fuels and synthetic compounds (IFOAM., 2009). For example, in livestock raising systems based on free-range grazing with minimal external inputs, waste from production of balanced feed and synthetic fertilizers is avoided and locally available resources are reused and recycled, maximizing positive interactions among crops, livestock, silviculture and other components of the physical environment (Nahed et al., 2018; Van-Wagenberg et al., 2017).

Furthermore, organic livestock raising provides more environmental services on a landscape level than does conventional livestock raising. Practices used in organic livestock production, for example, through agrosilvopastoral systems-increase biodiversity through creation of complex habitats which favor a wide range of plants and animals, host a rich soil biota and maximize connectivity among forest fragments. In temperate climates as well as in tropical climates such as that of the study region, agrosilvopastoral systems serve as wildlife corridors that provide food and refuge for fauna. Their combination of grasses and trees helps retain soil and water as well as prevent erosion of watersheds and consequently soil nutrient loss. 


\section{CONCLUSION}

The cluster analysis organized the 50 LPU evaluated into three groups: one $(\mathrm{C} 1)$ with very low values for the technical-economic indicators as well as for eight of the ten indicators of the index; another (C3) with generally, high values for the technical-economic indicators as well as for the index and the other (C2) with intermediate values for both the indicators and the index. The high viability of organic conversion of the LPU of C3 is due to traditional management with low use of external inputs more than use of sustainable organic farming technologies.

The LPU of the three clusters appear to be very viable for conversion to the organic production model with respect to the indicators "soil fertilization" and "breeds and reproduction". The LPU of C3 and C2 are very viable for conversion with respect to the indicators "feeding management" and "weed and pest control". The LPU of $\mathrm{C} 1$ are highly limited for eight of the ten indicators and the indicators "veterinary prevention and care" and "ecological farm management" strongly limit conversion of all three clusters.

There is a need for all farmers of the LPU evaluated to strengthen the ten indicators and the variables that make them up, particularly with respect to the indicators "sustainable grassland management", "soil fertility", "veterinary prevention and care", "food safety" and "ecological farm management". We recommend that government agencies and NGOs implement a policy involving training, technical assistance and financial support, so that, livestock farms may rapidly transition toward organic certification, offer healthy products (meat, milk and cheese) and market their products at higher prices. The greater net margin and economic efficiency of $\mathrm{C} 3$ and $\mathrm{C} 2$ farms as compared to that of $\mathrm{C} 1$ farms allows for greater economic reinvestment in these LPU which could allow them to more quickly achieve organic certification.

$\mathrm{C} 1$ and $\mathrm{C} 2$ has an ICOGAN within termediate potential of organic conversion. $\mathrm{C} 3$ has an ICOGAN which indicates high potential for organic conversion. There is a need for farmers and technical advisors to follow organic regulations with respect to management techniques as well as permitted, restricted and prohibited substances. Conversion of LPU to organic production depends on farmers further developing their abilities to manage sustainable agricultural systems through advisory, technical assistance and permanent financial support. There is also a need for all social actors involved to be committed to the conversion process as well as for significant changes in state and federal livestock raising policies which facilitate the LPU's transitioning toward organic certification, so that, that may offer healthy products (meat, milk and cheese) and continue their biological and social reproduction while being economically viable.

\section{ACKNOWLEDGEMENT}

Special thanks to the academic assistant MSc. Romeo Trujillo Vazquez for field support and to participating livestock farmers from Tecpatan, Chiapas. This study received financial support from the projects "quantification of enteric methane and nitrous oxide emissions in cattle raising in grazing and design of strategies for their mitigation in Southeastern Mexico [CONACYT-SEP cb 2014-No. 242541]" and "Transversal multidisciplinary family agriculture project [CONACYT 2015-2018-No. $1106610270]^{\prime}$.

\section{REFERENCES}

Bellon S. and C. Lamine, 2009. Conversion to Organic Farming: A Multidimensional Research Object at the Crossroads of Agricultural and Social Sciences-A Review. In: Sustainable Agriculture, Lichtfouse, E., M. Navarrete, P. Debaeke, S. Veronique and C. Alberola (Eds.). Springer, Dordrecht, New York, USA., ISBN:978-90-4812665-1, pp: 653-672.

Coffey, L., J. Reynolds and M. Hale, 2010. Small ruminant sustainability checksheet. ATTRA, Melbourne, Australia. https://attra.ncat.org/attrapub/download.php?id=340

Cook, S.M., Z.R. Khan and J.A. Pickett, 2007. The use of push-pull strategies in integrated pest management. Annu. Rev. Entomol., 52: 375-400.

De Boer, I.J.M., 2003. Environmental impact assessment of conventional and organic milk production. Livestock Prod. Sci., 80: 69-77.

Delgado-Pertinez, M., R. Gutierrez-Pena, Y. Mena, V.M. Fernandez-Cabanas and D. Laberye, 2013. Milk production, fatty acid composition and vitamin E content of Payoya goats according to grazing level in summer on Mediterranean shrublands. Small Ruminant Res., 114: 167-175.

Escribano, A., 2016. Beef cattle farm's conversion to the organic system: Recommendations for success in the face of future changes in a global context. Sustainability, 8: 1-23.

Falconi, F. and R. Burbano, 2004. Economic tools for environmental management: Mono-criteria vs. multi-criteria decisions. Rev. Iberoamericana Econ. Ecol., 1: 11-20.

Grimm, J.W. and P.R. Wozniak, 1990. Basic Social Statistics and Quantitative Research Methods. Wadsworth publishing Co., Belmont, CA USA, ISBN-13: 9780534125943, Pages: 493.

Hersleth, M., T. Naes, M. Rodbotten, V. Lind and E. Monteleone, 2012. Lamb meat-Importance of origin and grazing system for Italian and Norwegian consumers. Meat Sci., 90: 899-907. 
IFOAM., 2009. One Earth, many minds. International Federation of Organic Agriculture Movements, Bonn, Germany.

IFOAM., 2018. Principles of organic agriculture. IFOAM-Organics International Nonprofit Organization, Bonn, Germany. https://www.ifoam.bio/en/organic-landmarks/ principles-organic-agriculture

Jose, S., 2009. Agroforestry for ecosystem services and environmental benefits: An overview. Agrofor. Syst., 76: 1-10.

Kouba, M., 2003. Quality of organic animal products. Livest. Prod. Sci., 80: 33-40.

Lernoud, J. and B. Schlatter, 2016. Latin America and the Caribbean: Current statistics. In: The world of organic agriculture: Statistics and Emerging Trends, Willer, H. and J. Lernoud (Eds.). Research Institute of Organic Agriculture FiBL, IFOAM Organics International, Frick, Switzerland, ISBN:978-3-03736-307-2, pp: 242-249.

Long, N. and M. Villareal, 1992. Exploring Agricultural Development Interfaces: From Knowledge Transfer to the Transformation of Meaning. In: Beyond Farmer First: Rural People's Knowledge Agricultural Research and Extension Practice, Scoones, I., J. Thompson and R. Chambers (Eds.). University of Sussex, Brighton, England, UK., pp: 27-29.

Mehta, C.R. and N.R. Patel, 2011. IBM SPSS Exact Tests. IBM Corporation, Armonk, New York, USA., Pages: 226.

Mena, Y., J. Nahed, F.A. Ruiz, B. Sanchez-Munoz, J.L. Ruiz-Rojas and J.M. Castel, 2012. Evaluating mountain goat dairy systems for conversion to the organic model, using a multicriteria method. Animal, 6: 693-703.

Mena-Guerrero, Y., F.A. Ruiz-Morales, J.M. CastelGenis and M. Ligero-Casado, 2009. Proximity to the organic model of dairy goat systems in the Andalusian mountains (Spain). Trop. Subtropical Agroecosyst., 11: 69-73.

Midmore, P., S. Padel, H. McCalman, J. Isherwood, S. Fowler and N. Lampkin, 2001. Attitudes Towards Conversion to Organic Production Systems: A Study of Farms in England. University of Wales, Aberystwyth, UK., Pages: 71.

Muller-Lindenlauf, M., C. Deittert and U. Kopke, 2010. Assessment of environmental effects, animal welfare and milk quality among organic dairy farms. Livest. Sci., 128: 140-148.

Munda, G., 2004. Multicriteria methods and multicriteria processes for social evaluation of public policy. Rev. Iberoam. Economia Ecol., 1: 31-45.
Munda, G., P. Nijkamp and P. Rietveld, 1994. Fuzzy Multigroup Conflict Resolution for Environmental Management. In: The Economic of Project Appraisal and the Environment, Weiss, J. (Ed.). Edward Elgar, Aldershot, Hampshire, UK., pp: 161-183.

Nahed, J., J.M. Castel, Y. Mena and F. Caravaca, 2006. Appraisal of the sustainability of dairy goat systems in Southern Spain according to their degree of intensification. Livest. Sci., 101: 10-23.

Nahed, J., S. Gonzalez-Pineda, D. Grande, J.R. Aguilar and B. Sanchez et al., 2018. Evaluating sustainability of conventional and organic dairy cattle production units in the Zoque Region of Chiapas, Mexico. Agroecology Sustainable Food Syst., 43: 605-638.

Nahed-Toral, J., B. Sanchez-Munoz, Y. Mena-Guerrero, J. Ruiz-Rojas and R. Aguilar Jimenez et al., 2012. Potential for conversion of agrosilvopastoral systems of dairy cattle to the organic production model in South Eastern Mexico. J. Anim. Vet. Adv., 11: 3081-3093.

Nahed-Toral, J., B. Sanchez-Munoz, Y. Mena, J. RuizRojas and R. Aguilar-Jimenez et al., 2013. Feasibility of converting agrosilvopastoral systems of dairy cattle to the organic production model in Southeastern Mexico. J. Cleaner Prod., 43: 136-145.

Nahed-Toral, J., H. Gomez-Castro, R. Pinto-Ruiz, F. Guevara-Hernandez, F. Medina-Jonapa, M. Ibrahim and D. Grande-Cano, 2010. Research and development of silvopastoral systems in a village in the buffer zone of the El Ocote Biosphere Reserve, Chiapas, Mexico. Res. J. Biol. Sci., 5: 499-507.

Napolitano, F., G. De Rosa, V. Ferrante, F. Grasso and A. Braghieri, 2009. Monitoring the welfare of sheep in organic and conventional farms using an ANI 35 L derived method. Small Ruminant Res., 83: 49-57.

Nauta, W.J., T. Baars and H. Bovenhuis, 2006. Converting to organic dairy farming: consequences for production, somatic cell scores and calving interval of first parity Holstein cows. Livestock Sci., 99: 185-195.

Olivares, P.R., C.M. Gomez and A.M. Meraz, 2005. Potential for conversion of conventional livestock farms to organic production systems in the State of Tabasco. Rev. Tec. Pecuaria Mex., 43: 361-370.

Ortiz, L.C., 1982. Cattle production in Tabasco and Northern Chiapas. Rev. Geografia Agricola, Mex., 3: 117-134.

Peacock, C. and D.M. Sherman, 2010. Sustainable goat production-Some global perspectives. Small Ruminant Res., 89: 70-80. 
Phythian, C.J., E. Michalopoulou, P.H. Jones, A.C. Winter and M.J. Clarkson et al., 2011. Validating indicators of sheep welfare through a consensus of expert opinion. Anim., 5: 943-952.

Reganold, J.P. and J.M. Wachter, 2016. Organic agriculture in the twenty-first century. Nat. Plants, 2: $1-8$.

Rozzi, P., F. Miglior and K.J. Hand, 2007. A total merit selection index for ontario organic dairy farmers. J. Dairy Sci., 90: 1584-1593.

Scarnecchia, D.L. and M.M. Kothmann, 1982. A dynamic approach to grazing management terminology. J. Range Manage., 35: 262-264.

Scoones, I., 1998. Sustainable rural Livelihoods: A framework for analysis. IDS Working Paper 72, Institute of Development Studies, University of Sussex.

UNICEF., 2016. UNICEF's strategy for health (2016-2030). The United Nations International Children's Emergency Fund, New York, USA. https://www.unicef.org/health/files/170601_Strateg y_for_health_2016-30_report_Spanish.pdf.
Vaarst, M., S. Padel, M. Hovi, D. Younie and A. Sundrum, 2005. Sustaining animal health and food safety in European organic livestock farming. Livest Prod. Sci., 94: 61-69.

Van-Wagenberg, C.P.A., Y. De Haas, H. Hogeveen, M.M. Van Krimpen and M.P.M. Meuwissen et al., 2017. Animal board invited review: Comparing conventional and organic livestock production systems on different aspects of sustainability. Anim., 11: 1839-1851.

Vasta, V., V. Ventura, G. Luciano, V. Andronico and R.I. Pagano et al., 2012. The volatile compounds in lamb fat are affected by the time of grazing. Meat Sci., 90: 451-456.

Von Borell, E. and J.T. Sorensen, 2004. Organic livestock production in Europe: Aims, rules and trends with special emphasis on animal health and welfare. Livest. Prod. Sci., 90: 3-9.

Zar, J.H., 1984. Biostatistical Analysis. 2nd Edn., Prentice-Hall Inc., Englewood Cliffs, New Jersey, USA. 